\title{
Directional analysis of drainage network and morphotectonic features in the south-eastern part of Bükk Region
}

\author{
PÉTer PECSMÁN $Y^{1}$, ANdrás HEGEDÚS ${ }^{1}$, János V ÁGÓ ${ }^{1}$ and Norbert NÉMETH ${ }^{2}$
}

\begin{abstract}
The fracture deformations often result in linear morphological elements (lineaments, valleys) on the surface. In many cases, the direction of the lineaments and valleys can be well followed by the strike of the geological structural elements. Therefore, conclusions can be drawn from these directions for regional tectonic processes. Our work aimed to analyse the relationship between the valley and lineament network and the structural elements in the south-eastern part of Bükk Region. We prepared the theoretical drainage network map and lineament map of the area. The direction of the linear elements was examined separately on the eastern part of South-Eastern Bükk that is built up mainly by Mesozoic limestone and the eastern side of Bükkalja area covered by Neogene and Quaternary sediments. Structural geological surveys were also performed on seven sites to measure the strike of joint sets. These results were compared with the valleys' direction in the $2 \mathrm{~km}$ wide area of the measurement sites. Based on our results, it can be stated that the development of the drainage network was influenced by the geological elements; however, there are local differences in the characteristics of the South-Eastern Bükk and Bükkalja. Our study confirmed that the study of linear morphological elements has great importance in the exploration of geological structural elements.
\end{abstract}

Keywords: drainage, lineament, directional analysis, structurally controlled streams, tectonic preformation, morphotectonics, Bükk Mountains, Bükkalja

Received: April 2021, accepted June 2021

\section{Introduction}

On the surface, faults often cause linear geomorphological structures called lineaments (Twiss, R.J. and Moores, E.M. 1992; JordáN, Gy. and Csillag, G. 2003; RADAideh, O.M.A. et al. 2016). In the dissected zones weakened by faults, the erosion is more effective, therefore valleys often form along with these structural elements (MARTz, L.W. and GARbrecht, J. 1992). Besides the valleys, lineaments can be geomorphological units like ridges, escarpments (Twiss, R.J. and Moores, E.M. 1992; Jordán, Gy. and Csillag, G. 2003; RAdaideh, O.M.A. et al. 2016). Measuring and analysing the direction of lineament and drainage network is important, because we can infer the directions of the main strike of geological structural elements (Twiss, R.J. and Moores, E.M. 1992; EyLEs, N. et al. 1997). Mapping lineament and drainage network is relevant both in geomorphological and structural geological research because these are in association with the regional structural processes (RAMSAY, J.G. and Huber, M.I. 1985; Twiss, R.J. and Moores, E.M. 1992; Centamore, E. et al. 1996; Eyles, N. et al. 1997; Jordán, Gy. and Csillag, G. 2003; Dombrádi, E. et al. 2007; RUSZKICZAY-RÜDIGER, Zs. et al. 2007, 2009; RADAideh, O.M.A. et al. 2016; Gioia, D. et al. 2018).

The structural evolution of the south-eastern part of Bükk Region was directed by varied ge-

\footnotetext{
${ }^{1}$ Institute of Geography and Geoinformatics, University of Miskolc, H-3515 Miskolc, Miskolc-Egyetemváros. E-mails: ecopeter@uni-miskolc.hu, ecoeged@uni-miskolc.hu, ecovago@uni-miskolc.hu

${ }^{2}$ Department of Geology and Mineral Deposits, University of Miskolc, H-3515 Miskolc, Miskolc-Egyetemváros. E-mail: foldnn@uni-miskolc.hu
} 
ological processes since the Eocene (Csontos, L. 1988, 1999; Márton, E. and Fodor, L. 1995; Less, Gy. et al. 2005; Németh, N. 2005; Petrik, A. et al. 2014, 2016). Some of these processes caused the development of structurally preformed valleys. Some valley sections of Tárkány-, Eger-, Ostoros-, Kánya-, Hór-, Tard-, Kács-, Sály-, and Kulcsárvölgy stream were formed along faults (SCHRÉTER, Z. 1912, 1926, 1933; Balogh, K. 1963; Less, Gy. et al. 2005; Németh, N. 2005; Petrik, A. 2016; Pecsmány, P. et al. 2020; Pecsmány, P. and VÁGó, J. 2020). In the northern part of Bükk Region and its northern foreland SzALAI, K. (2004) proved the structurally preformed characteristics of the valleys by direction statistical analysis.

Our hypothesis is that the structural characteristics directed the geomorphic evolution of the South-Eastern Bükk Region and the development of the area's drainage network. In this paper, we proved the relationship between the geological structural elements and the linear elements (lineaments and valleys) by direction statistical analysis.
Sajó Valley. The boundary of the microregions can be drawn along the fault lines between the Mesozoic and Cenozoic rock formations (Doвоs, A. 2002). Two sub-mountain basins can be found at this boundary with different geological features and geomorphological landscapes; the Kács Basin and the Kisgyőr Basin (Figure 1) (Hevesi, A. 2003; Pecsmány, P. 2017).

\section{Geology and geomorphology of the research area}

The geomorphology (Hevesi, A. 1978, 2002a,b; Hevesi, A. and ZÁnorszki, A. 2000) and the geological characteristics of the South-Eastern Bükk (Csontos, L. 1988; 1999; Pentelényi, L. 2002; 2005; Németh, N. 2005) and the Bükkalja (Doвos, A. 2002; VÁGó, J. and Hegedús, A. 2010; Petrik, A. 2016; Pecsmány, P. 2017) are well known. However, the eastern side of Bükkalja has not yet been examined in details from a geomorphological and geological point of view. The average height above sea level is $250 \mathrm{~m}$. The relative relief is $130 \mathrm{~m} / \mathrm{km}^{2}$ of the whole research area, but there is a significant difference between the geology and geomorphology of the mountainous and hilly parts.

\section{Research area}

\section{Location}

Based on the official Hungarian landscape classification, the research area $\left(291 \mathrm{~km}^{2}\right)$ is situated in the south-eastern part of the Bükk Region, microregion group of the North Hungarian Mountain Range region (CsorbA, P. et al. 2018). The north-western part of the area $\left(65 \mathrm{~km}^{2}\right)$ belongs to the mountainous microregion of South-Eastern Bükk (Hevesi, A. 2003), the southeastern hills $\left(226 \mathrm{~km}^{2}\right)$ are located on the eastern part of Bükkalja foothills microregion (CsorbA, P. et al. 2018), while the north-eastern part is the western side of the

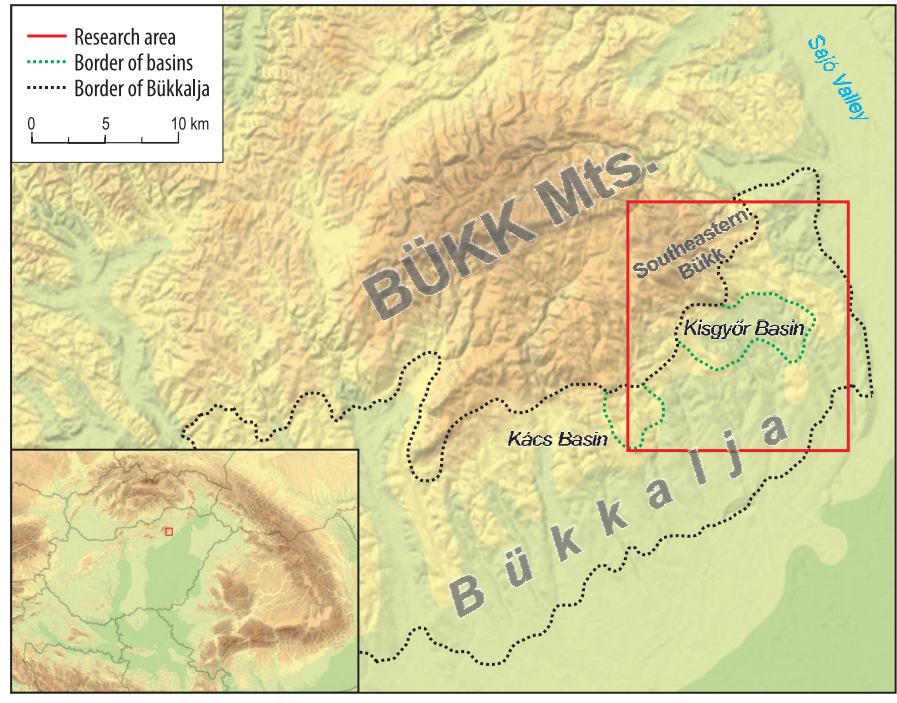

Fig. 1. Location and topography of the research area 


\section{South-Eastern Bükk area}

The average height above sea level is $472 \mathrm{~m}$, with the highest point is $719 \mathrm{~m}$, the lowest one is $129 \mathrm{~m}$ a.s.l. The relative relief is $212 \mathrm{~m} / \mathrm{km}^{2}$. This mountainous region is mainly composed of strongly karstified Triassic limestone (Berva Limestone, Bükkfennsík Limestone) with dolines, sinkholes, cave springs and less karstified cherty limestone (Felsőtárkány Limestone) without dolines and caves (Hevesi, A. and ZÁHorszKI, A. 2000; Less, Gy. et al. 2005). Triassic metavolcanic rocks (Szentistvánhegy Metavolcanics, Szinva Metabasalt) can be found in the northern part of the area. In some places, there is saccharoidal dolomite (Belvács Dolomite), Jurassic shale (Lökvölgy Formation) and radiolarite (Bányahegy Radiolarite Formation) on the surface (Figure 2; LEss, Gy. et al. 2005).

\section{Bükkalja area}

The average height above sea level is $185 \mathrm{~m}$. The highest point is $505 \mathrm{~m}$, the lowest one is $104 \mathrm{~m}$ above sea level. The relative relief is $95 \mathrm{~m} / \mathrm{km}^{2}$. Cenozoic deposits cover these Mesozoic rocks in the area of the Bükkalja due to vertical fault displacements (BALOGH, K. 1963; Less, Gy. et al. 2005; Németh, N. 2005; Petrik, A. 2016). The main rock types are Eocene limestone and calcareous marl (Szépvölgy Limestone), Oligocene clay and clayey marl silt (Buda Marl, Kiscell Clay) in the North (Less, Gr. et al. 2005); variable-stability Miocene pyroclastics (sometimes ignimbrite) produced by the periodic volcanic activity (LukÁcs, R. et al. 2018) (Gyulakeszi Rhyolite Tuff Formation, Tar Dacite Tuff, Harsány Rhyolite Tuff) in the middle (LEss, Gr. et al. 2005); sedimentary rocks of former Lake Pannon (Egyházasgerge Formation, Sajóvölgy Formation, Zagyva Sand, Edelény Clay) in the South (Less, Gy. et al. 2005) (see Figure 2). Due to the differential weathering of volcanic tuffs, there is sandy, gravelly colluvium (grézes litées) on the gentle slopes (Pinczés, Z. et al. 1993), which was often re-
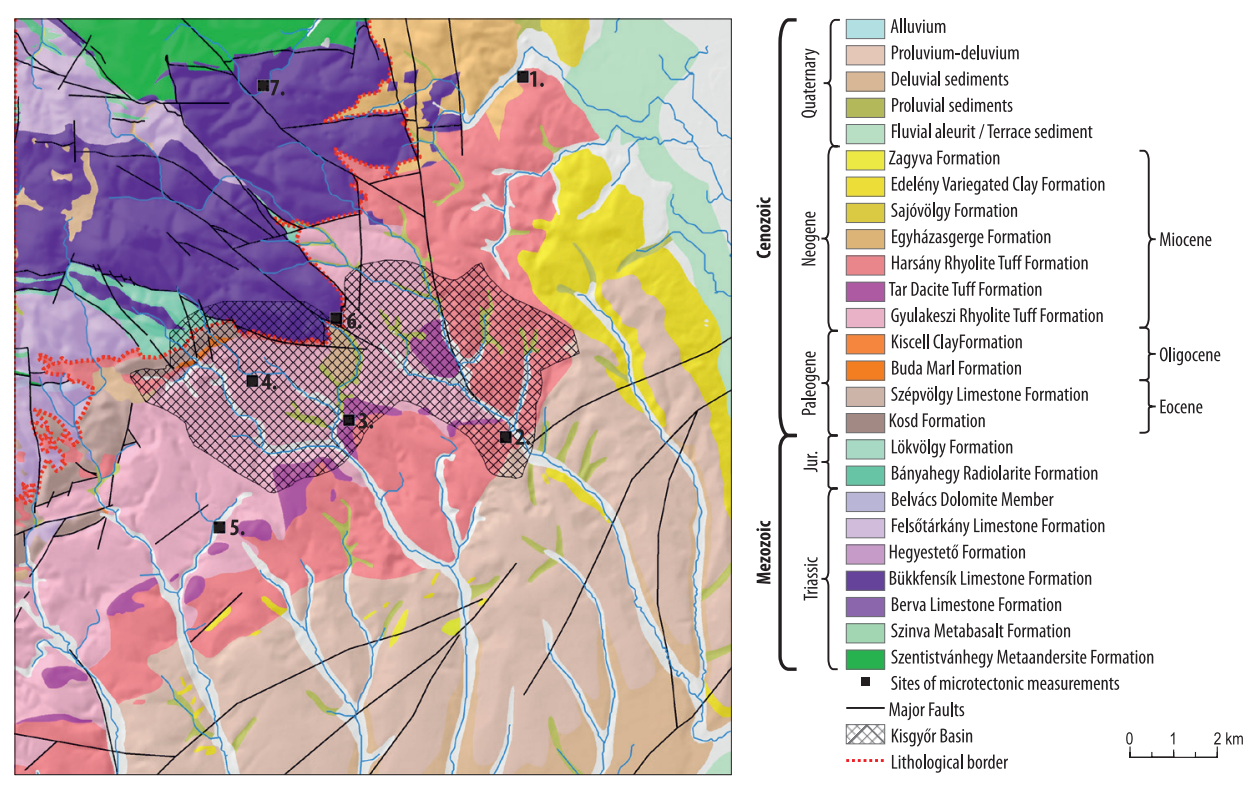

Fig. 2. Geological map of the research area (Gyalog, L. and SíkHEgyi, F. 2005), major faults (Less, Gy. et al. 2005; NÉMeth, N. 2005; Petrik, A. 2016) and the sites of microtectonic measurements 
deposited by fluvial erosion and downhill mass movements. South of the tuff outcrops, with a gradual decrease in clay content, loess, resedimented loess, sand, gravel is typical (Less, Gy. et al. 2005; see Figure 2).

\section{Materials and methods}

\section{The drainage network of the research area}

In areas where drainage density is low (such as in Bükkalja), instead of the streams, the valleys are often used for direction statistical analysis in structural morphological research (MARtz, L.W. and GARbrecht, J. 1992; Ruszkiczay-Rüdiger, Zs. et al. 2007, 2009). The valleys were extracted from a digital elevation model using ArcGIS "Fill", "Flow Direction" and "Flow Accumulation" tools. The DEM (cell size: $25 \times 25 \mathrm{~m}$ ) was interpolated using digitized contour lines and elevation points of topographic maps scale 1:10,000. In our research, we considered only those DEM pixels as parts of valleys, which have a catchment area bigger than 150 pixels $\left(\sim 0,1 \mathrm{~km}^{2}\right)$. Then we vectorised the valley pixels, this polyline network draws the valley network. Since the orientation of the valley network was compared with the deep structural elements' direction, the smaller oscillations of valley sections were smoothed by the Demeter, G. and Szabó, Sz. (2009) method, applying the ArcGIS "Generalization" tool. Using the breakpoints (vertices) of the valleys, we split each curve to straight line segments. The distances of vertices as valley length, and the coordinates of these vertices were used for the calculation of the direction of the segments, applying the RockWorks 16 software. The valley sections' Strahler-orders (Strahler, A.N. 1957) were defined by the ArcGIS "Stream Order" tool. The directions and direction frequencies were plotted on rose diagrams with 10-degree scale interval using RockWorks 16 "Creating Rose Diagrams from Endpoint Data" tool. The rose diagrams were analysed by traditional visual interpreting methods (RICCHETti, E. and
Palombella, M. 2007; Radaideh, O.M.A. et al. 2016; Petrik, A. and Jordán, Gy. 2017; Gioia, D. et al. 2018).

\section{Lineament mapping}

There are many methods to identify and digitize lineaments. Visual interpretation of satellite images (LEECH, D.P. et al. 2003; UNGer, Z. and Timár, G. 2005; AL-RAwAshdeh, S. et al. 2006), digital elevation models and its derivatives (RADAIDEH, O.M.A. et al. 2016; Petrik, A. and Jordán, Gy. 2017), or both of them together (ChAAвouni, R. et al. 2012) is usually applied, but subjective technique. Striving for objectivity, in our research, we used the method published by Al-Obeidat, F. et al. (2016) for mapping lineaments. This method analyses the hillshade, a DEM derivative as an image by a Canny edge detection algorithm. Hillshades were created in ArcGIS 10.1 software, and then the edge detection algorithm was run on them in MatLab R2017b software. The result rasters were vectorised in ArcGIS 10.1. Then the polylines were smoothed using ArcGIS "Generalization" tool. Only lines longer than $500 \mathrm{~m}$ were considered lineaments (Figure 3) because these are more likely associated with fault lines than shorter ones. Directions and direction frequencies of lineaments were plotted on rose diagrams.

\section{Microtectonic measurements}

Microtectonic observations were made during field trips. In this study, measurements of subvertical joints were used only. Dip data of 925 faults/joints were measured in 7 exposures (see Figure 2) by a Freiberg-type geologic compass and Field Move Clino IOS mobile application (SMITH, S. et al. 2014; LUNDMARK, M.A. et al. 2020) (without declination correction). Strike frequency was plotted on a rose diagram with a 10-degree scale interval using RockWorks 16 software. It is important to note that not only the spacing but also the exposure 


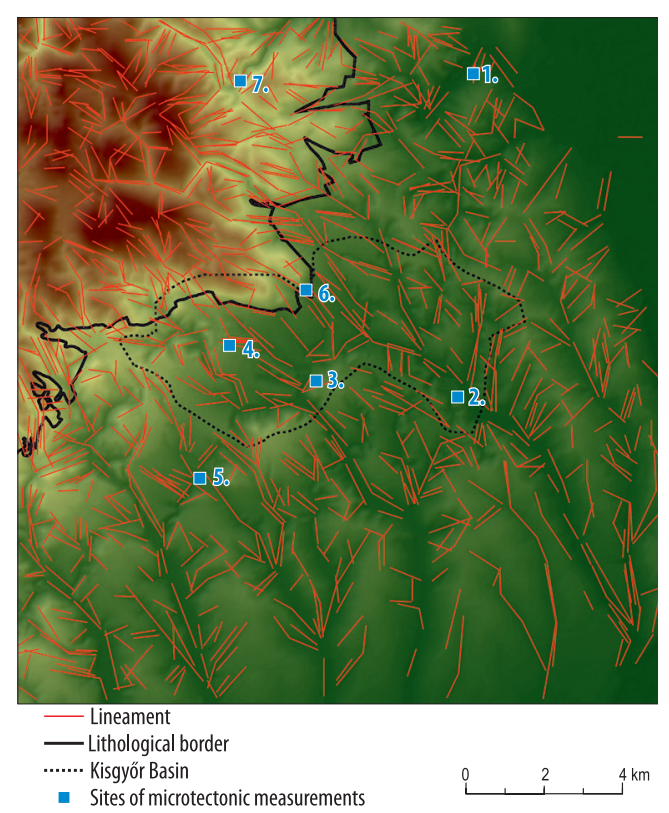

Fig. 3. Lineament map created by the method of Al-Obeidat, F. et al. (2016).

orientation of the site influences the number of measurements on joints if differently oriented joint sets (e.g. in the case of a with E-W oriented section, the number of detected N-S joints will be much higher than of the E-W striking ones). Therefore, in contrast with the topographic lineaments, differences of actual magnitude in local maxima on the diagrams may reflect this and not the relative abundance of the joints belonging to the joint sets characterized by a certain orientation.

\section{Results}

\section{Strike of faults and other planar structural features}

We wanted to compare the directions of the morphological linear elements and the mapped (Less, Gy. et al. 2005; NÉmeth, N. 2005; Petrik, A. 2016) and measured (Petrik, A. 2016) geological structural elements; therefore, we also examined their directional statistics.
The direction frequency of the planar structures mapped so far in the area shows a bimodal distribution. The E-W and N-S directions are the most common. Even in direction frequency weighted by length, a bimodal character can be observed in the N-S and NW-SE directions (Figure 4). In the Bükkalja, Petrik, A. (2016) measured ESEWNW and NW-SE conjugate normal faults and joints strikes, NE-SW trending dextral and NW-SE sinistral strike-slip, E-W strike reverse faults.

Drainage network and lineament directions of the South-Eastern Bükk and Bükkalja area

The direction and direction by length of the valleys are E-W on the South-Eastern Bükk area. On the lineaments' diagrams, the major direction is between E-W and NW-SE (Figure 5).

On the Bükkalja area direction frequency of the valleys is undirected, however, the direction by length-frequency shows a dominantly NW-SE direction. The dominant directions of the lineaments on the foothill area are NW-SE and N-S (see Figure 5).

\section{Direction frequency and direction frequency by} the length of the valleys by their order

Analysing the direction frequency (per cent of the total population) of the valleys by their order on the entire research area, it can be stated that the $1^{\text {st }}$ order valley sections are undirected (Figure 6).

In the case of $2^{\text {nd }}$ order valleys, the primary direction is the E-W, but many of the valley sections have a NW-SE direction. Most of the $3^{\text {rd }}$ order valleys have a N-S direction; however, the most common direction by the valley length is NNW-SSE. In the case of $4^{\text {th }}$ order valleys, the main direction is NW-SE (Figure 6).

We also analysed the valley network separately on the South-Eastern Bükk and Bükkalja area. In the South-Eastern Bükk, the $1^{\text {st }}$ and $2^{\text {nd }}$ order valleys have E-W direction, while the direction of $3^{\text {rd }}$ order sections 


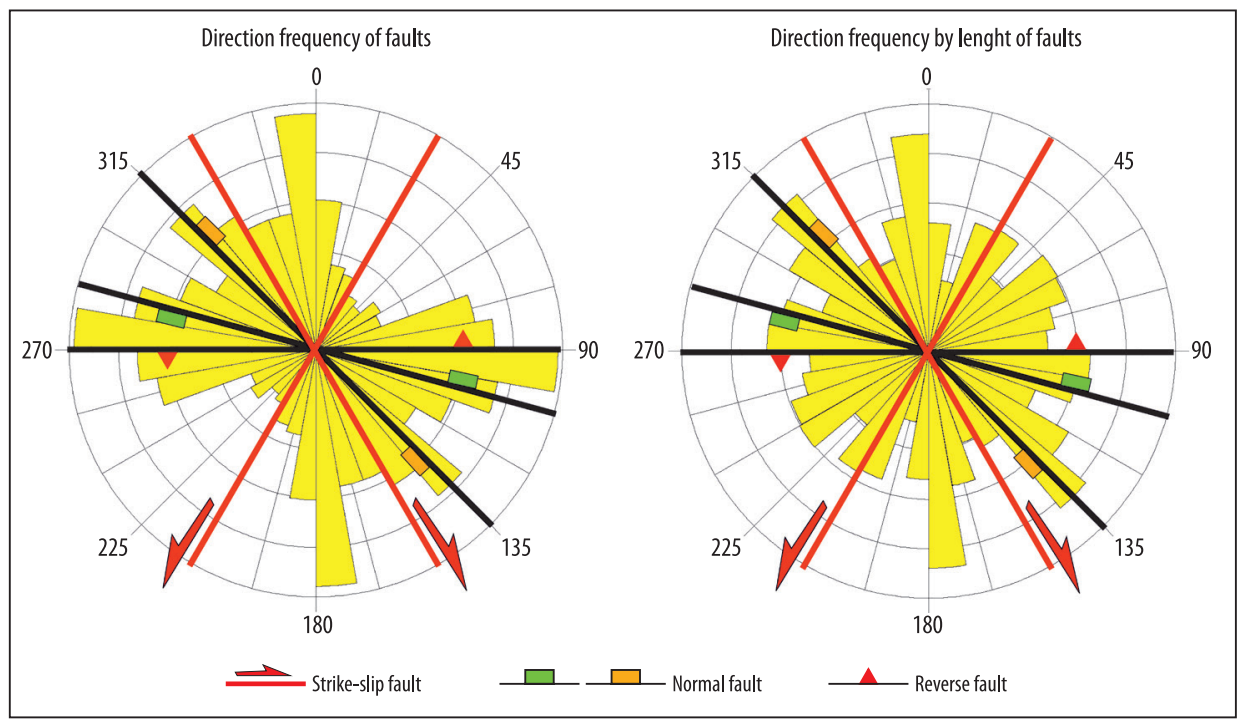

Fig. 4. Faults direction from geological map with PetrIK' s (2016) Pannonian-Pleistocene simplified fault kinematic

is $\mathrm{N}-\mathrm{S}$. In the direction frequency by length, the $1^{\text {st }}$ order valleys are undirected, the $2^{\text {nd }}$ order sections have E-W direction, and the $3^{\text {rd }}$ order ones have N-S direction (Figure 7).

In the Bükkalja area, both the direction and direction by the length of the $1^{\text {st }}$ order valleys is undirected. In case $2^{\text {nd }}$ order valleys, the main direction is E-W. There is also a secondary, NW-SE direction, which is the main direction on frequency by length diagram. The main direction of $3^{\text {rd }}$ and $4^{\text {th }}$ order valleys is NW-SE in case of both direction, and direction by length (see Figure 7).

Valley, lineament and joints strike directions of the microtectonic measurements sites

Within a radius of $2 \mathrm{~km}$ around all structural measurements sites, we examined the directions of the lineaments, valleys and joints (Figure 8).

The direction and direction by the length of the valley network is NW-SE, except the neighbourhood of measurement sites No. 2 and No. 7. Site No. 2 has a NNE-SSW domi- nant and a NW-SE secondary direction. In the case of site No. 7, the main direction is E-W, however, the NW-SE direction can be seen as well on the diagram see (Figure 8).

The lineaments' direction at site No. 1 and No. 2 is NNE-SSW, NW-SE at sites No. 3-6, while E-W at site No. 7. The directions of joints at the measurement sites No. 1, 2, 3, 5 is NE-SW, NNW-SSE at site No. 4, ESE-WNW at site No. 6, and N-S at site No. 7 (see Figure 8).

\section{Discussion}

The principal direction of the valleys coincides with the direction of the dominant aspect (VÁGó, J. 2012), transverse faults (Pecsmány, P. 2021), and Pannonian-Pleistocene conjugate normal faults and joints strike (Petrik, A. 2016) (Figure 9).

Relevant differences can be found in the directions of linear elements on the SouthEastern Bükk and Bükkalja area. The valleys of the South-Eastern Bükk, running on limestone, dolomite, metavolcanics and shale are grouped around the E-W direction. The 


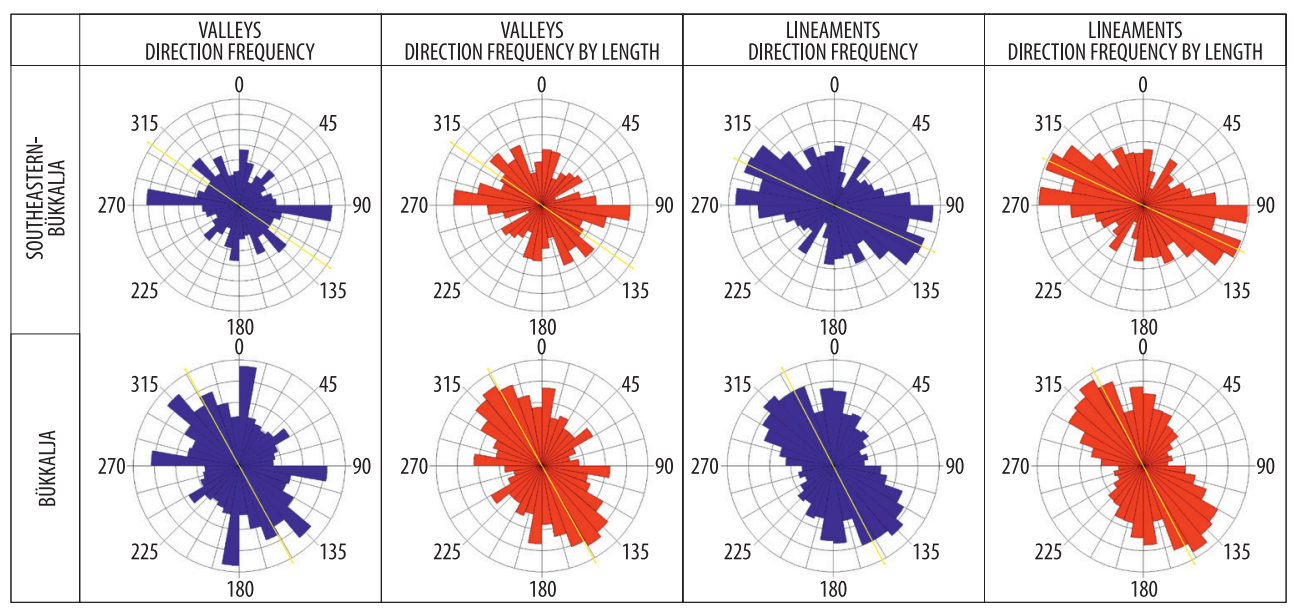

Fig. 5. Drainage network and lineament directions of the South-Eastern Bükk and Bükkalja area
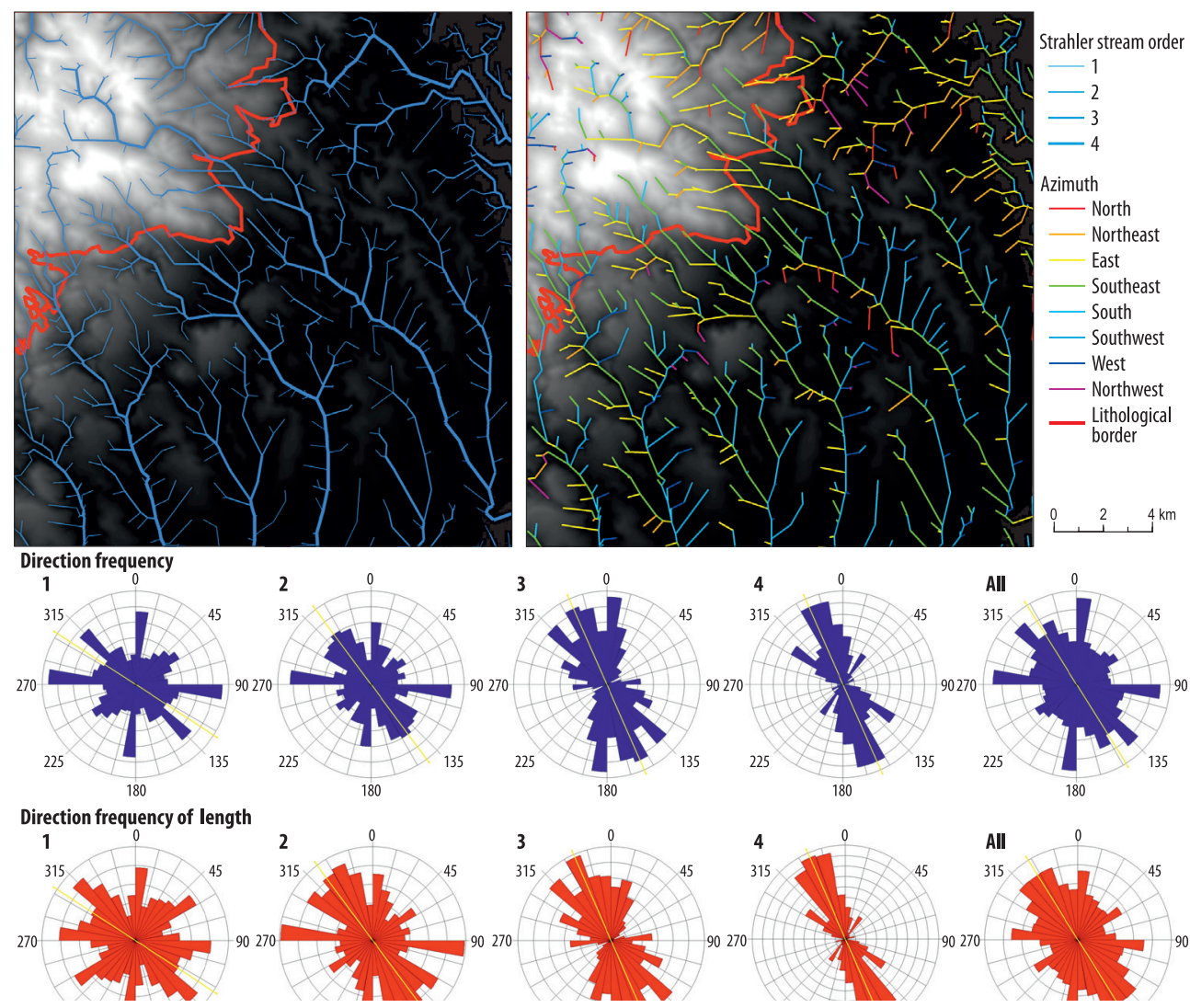

Fig. 6. Direction frequency of the valleys by their order on the entire research area. 


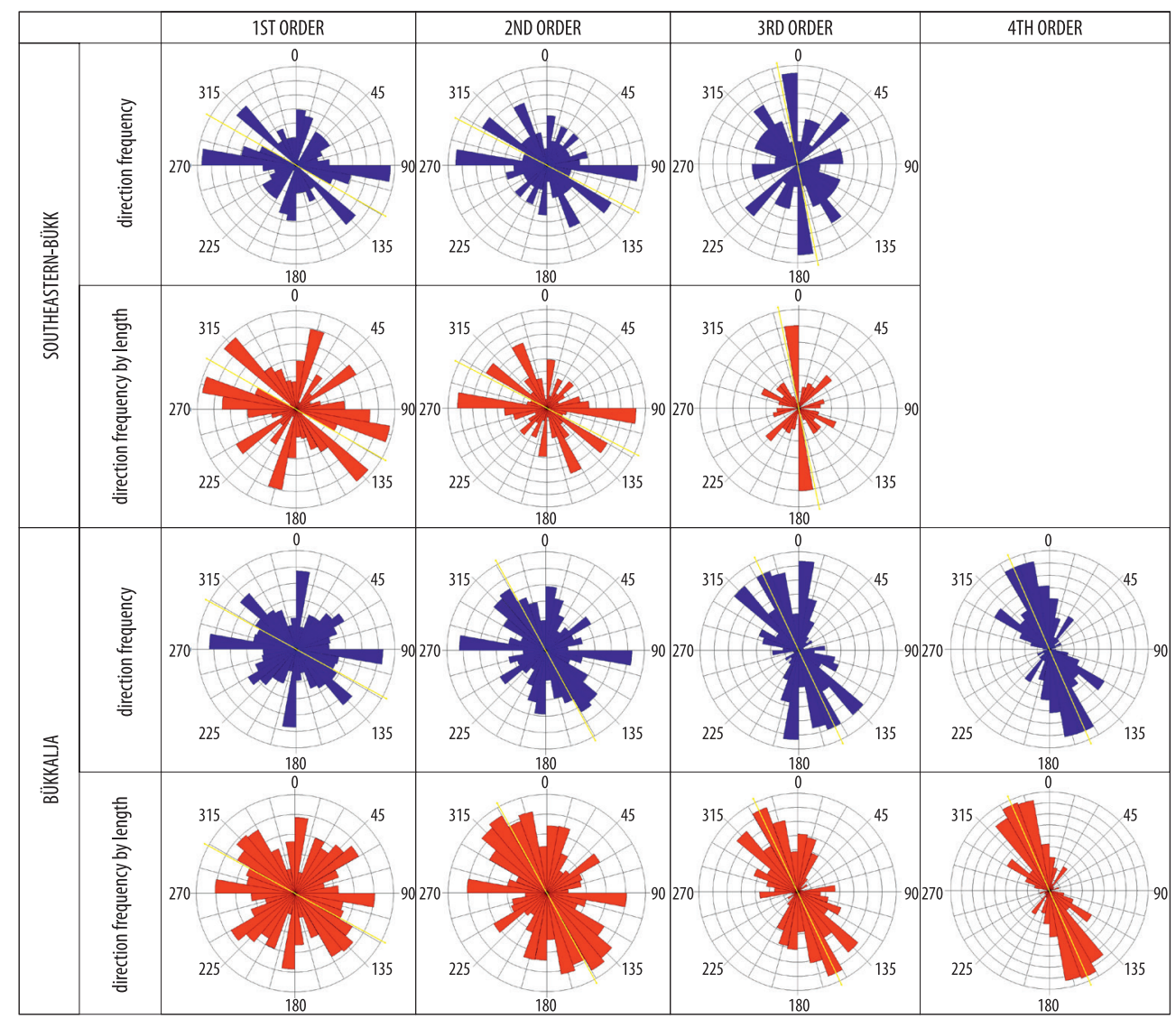

Fig. 7. Direction frequency and direction frequency by length on the South-Eastern Bükk and the Bükkalja area

direction of the foothill drainage network, running mostly on Miocene pyroclastics and Quaternary sediments, is almost "perpendicular" to this, N-S, NNW-SSE (see Figure 5).

The difference can also be observed for lineaments. The direction of the linear elements detected on the South-Eastern Bükk is between E-W and WNW-ESE direction. In the foothill area, the measured values are grouped around the NW-SE direction (see Figure 5). Similar to Ricchetti, E. and Palombella, M. (2007) and Radaideh, O.M.A. et al. (2016), we found that the direction frequency by length provides more reliable results.

Most valleys run more or less parallel to the cardinal directions, while the total length of the valleys has NW-SE direction (see Figure 6). The reason is that a large number of shorter, low-order valleys run parallel to the cardinal directions. In contrast, in the NW-SE direction less, but longer high-order valleys tend to run.

The direction frequency and the direction frequency by the length of the $2^{\text {nd }}, 3^{\text {rd }}$ and $4^{\text {th }}$ order valleys of the Bükkalja area are the same as the directions measured over the entire area (Figures 6 and 7). However, in the case of South-Eastern Bükk, there is a difference. Most of the $1^{\text {st }}$ order valleys are oriented to the E-W direction, weighting by the valley sections' length the dominant directions are WNW-ESE and the NNWSSE (see Figure 7). The $2^{\text {nd }}$ order valleys have 


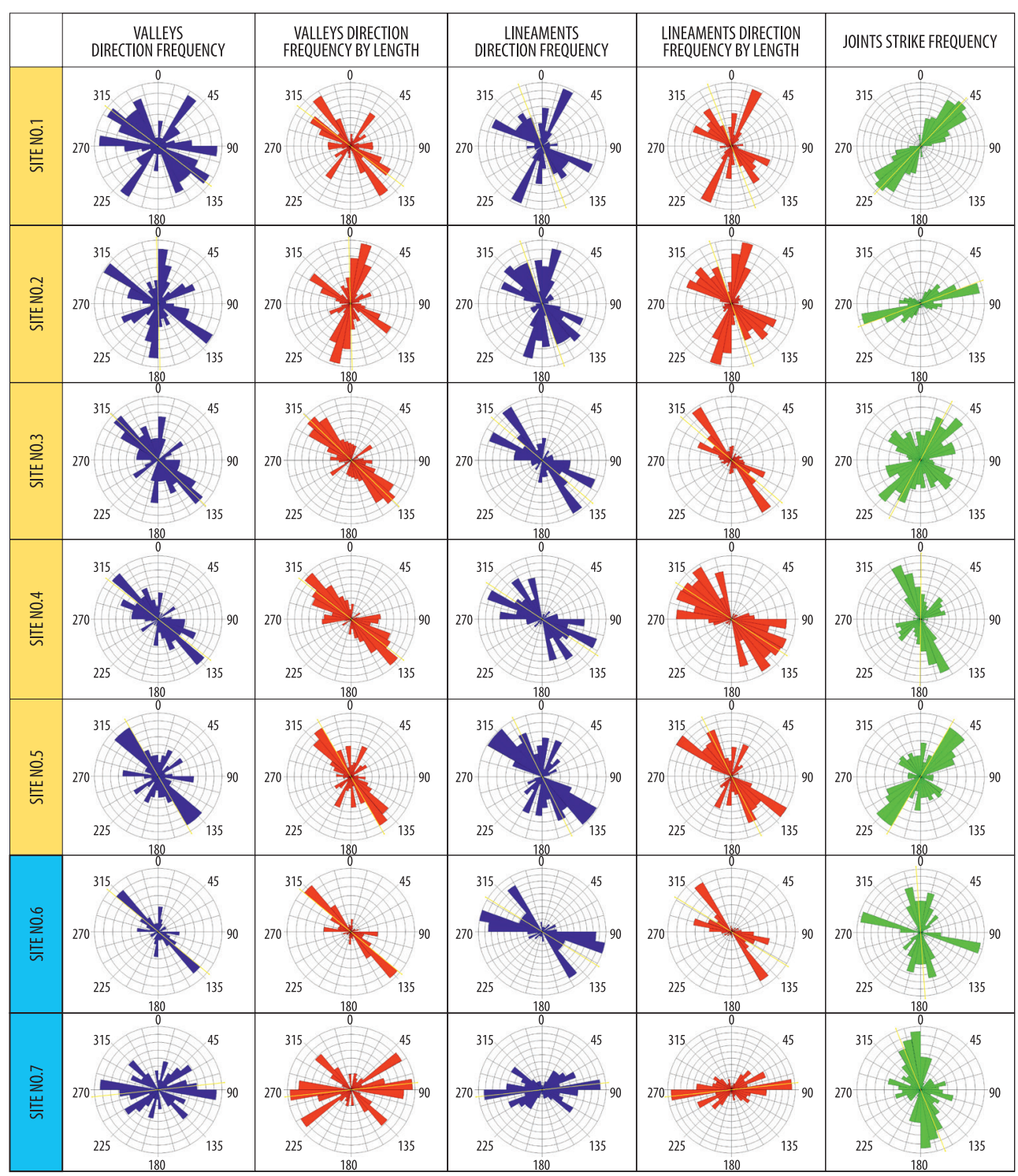

Fig. 8. Direction frequency and direction frequency by the length of valleys, lineaments and joints strikes at the measurement sites

mostly E-W direction. The most common direction of the $3^{\text {rd }}$ order valleys is N-S (see Figure 7).

In the South-Eastern Bükk, the $3^{\text {rd }}$ order valleys coincide with the main direction of the mapped geological structural elements. In the Bükkalja, the $2^{\text {nd }}, 3^{\text {rd }}, 4^{\text {th }}$ order valleys follow well the secondary direction of the mapped geological structural elements (see Figure 4). The undirected characteristics of $1^{\text {st }}$ order valleys on the Bükkalja can be explained by the valley density. This value is higher on the Bükkalja $\left(1.5 \mathrm{~km} / \mathrm{km}^{2}\right)$, than in the South-Eastern Bükk $\left(1.3 \mathrm{~km} / \mathrm{km}^{2}\right)$. 


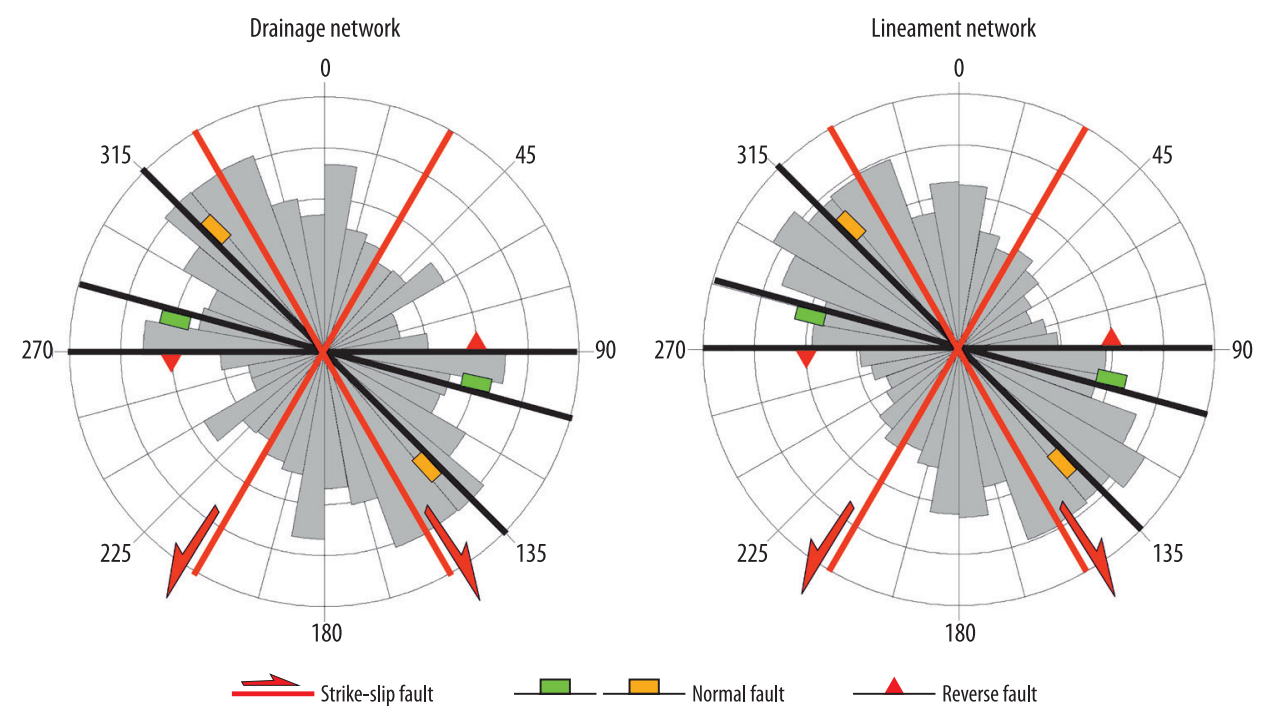

Fig. 9. Direction frequency by length of drainage and lineament network with Petrik's (2016) PannonianPleistocene simplified fault kinematic

According to Centamore, E. et al. (1996), the streams with lower order are directed by the recent tectonic activity, while the higher-order streams are following directions of the trending geological structural elements. In our study area, the directed/undirected characteristics of the low-order valleys were strongly influenced by the rock quality. However, the directions of the higher-order valleys coincide with the characteristic geological structural directions of the area. The result of the direction statistical analysis depends on the geological settings (rock quality) and the scale of valley order mapping.

The direction of joint sets strike coincides with the direction of valleys and lineaments (see Figure 8: site No. 1, 4 and 6) with a $\sim 15^{\circ}$ angular displacement. Most of the measured joint sets can be found in Miocene pyroclastic rocks, which petrographic characteristics are diverse on the Bükkalja (Less, Gr. et al. 2005; Pentelényi, L. 2005; Lukács, R. et al. 2018). The differences in rock quality may cause such angular displacements (DEMETER, G. and Szabó, Sz. 2009).

\section{Conclusions}

Our primary hypothesis was that structural movements determine the study area's surface development and drainage network formation. We analysed the directions of the valleys and lineaments and joint set strikes.

We found that the directions of the valley network coincide with the direction of the mapped and measured structural elements; however, there may be relevant local differences.

Despite the direction coincidence on the entire research area, there is a relevant difference between the drainage- and the lineament networks of the South-Eastern Bükk and the Bükkalja foothill area. Most of the lineaments and valleys are running in $\mathrm{W}-\mathrm{E}$ direction on the South-Eastern Bükk, while those running on the foothill are in NW-SE direction. There is also a difference in the direction of valley order segments. In the Bükkalja area, most of the $2^{\text {nd }}, 3^{\text {rd }}$ and $4^{\text {th }}$ order valleys run in NW-SE direction, while in the South-Eastern Bükk the direction of $2^{\text {nd }}$ order valleys is E-W, while the $3^{\text {rd }}$ order val- 
leys run in $\mathrm{N}-\mathrm{S}$ direction. The reason for this phenomenon requires further investigations.

Based on our examinations, it can be concluded that the structural development of the region strongly influenced the formation of the drainage network of the research area.

Acknowledgements: The described article/presentation/study was carried out as part of the EFOP-3.6.116-2016-00011 "Younger and Renewing University - Innovative Knowledge City - institutional development of the University of Miskolc aiming at intelligent specialization" project implemented in the framework of the Szechenyi 2020 Program. The realization of this project is supported by the European Union, co-financed by the European Social Fund.

\section{REFERENCES}

Al-Obeidat, F., Feltrin, L. and Marir, F. 2016. Cloud-based lineament extraction of topographic lineaments from NASA shuttle radar topography mission data. Procedia Computer Science 83. 1250-1255. Available at https://doi.org/10.1016/j. procs.2016.04.260

Al-Rawashdeh, S., Bassam, S. and Hamzah, M. 2006. The use of remote sensing technology in geological investigation and mineral detection in El AzraqJordan. European Journal of Geography, Systèmes, Modélisation, Géostatistiques 2856. 203-219.

BALOGH, K. 1963. A Bükk hegység és környékének földtani térképe 1:100 000. (Geological map of Bükk Mountains and its region $-1: 100,000)$. Budapest, MÁFI.

Centamore, E., Ciccacci, S., Del Monte, M., Fredi, P. and Lipia Palmieri, E. 1996. Morphological and morphometric approach to the study of the structural arrangement of north-eastern Abruzzo (Central Italy). Geomorphology 16. (2): 127-137. Available at https://doi.org/10.1016/0169555X(95)00138-U

Chahbouni, R., Bouaziz, S., Peresson, H. and WolfGang, J. 2012. Lineament analysis of South Jenein Area (Southern Tunisia) using remote sensing data and geographic information system. The Egyptian Journal of Remote Sensing and Space Science 15. (2): 197-206. Available at https://doi. org/10.1016/j.ejrs.2012.11.001

Csontos, L. 1988. Étude géologique d'une portion des Carpathes Internes: le massif du Bükk. PhD These, Lille, University of Lille.

Csontos, L. 1999. A Bükk hegység szerkezetének főbb vonásai (Structural outline of the Bükk Mountains). Földtani Közlöny 129. (4): 611-651.

Csorba, P., Ádám, Sz., Bartos-Elekes, Zs., Bata, T., Bede-Fazekas, Á., Czúcz, B., Csima, P., Csüllög,
G., Fodor, N., Frisnyák, S., Horváth, G., Illés, G., Kiss, G., Kocsis, K., Kollányi, L., KonKoly-Gyuró, É., Lepesi, N., Lóczy, D., Malatinszky, Á., MezősI G., Mikesy, G., Molnár, Zs., PÁsztor, L., Somodi, I., Szegedi, S., Szilassi, P., Tamás, L., Tirászi, Á. and VAsvárI, M. 2018. Landscapes. In National Atlas of Hungary: Natural environment. Ed.-in-chief: Kocsis, K., Budapest, Research Centre for Astronomy and Earth Sciences, Hungarian Academy of Sciences, 112-129.

Demeter, G and Szabó, Sz. 2009. A völgyhálózat és törésirányok kapcsolatának vizsgálata különbözó geoinformatikai módszerekkel a Bükk északi elöterén (Investigation of the relationship between the valley network and structure directions by different geoinformatics methods in the northern foreland of the Bükk Mountains). HunDEM 2009 and GeoInfo 2009 Conference. Miskolc, University of Miskolc, 1-20.

Dовоs, A. 2002. A Bükkalja II. felszínalaktani leírás (Geomorphology of Bükkalja II). In A Bükki Nemzeti Park. Ed.: Baráz, Cs., Eger, Bükki Nemzeti Park Igazgatóság, 217-228.

Dombrádi, E., Timár, G., BadA, G., Cloetingh, S. and Horváth, F. 2007. Fractal dimension estimations of drainage network in the Carpathian-Pannonian system. Global and Planetary Change 58. 197-213. Available at http://dx.doi.org/10.1016/j.gloplacha.2007.02.011

Eyles, N., Arnaud, E., Scheidegger, A.E. and Eyles, C.H. 1997. Bedrock jointing and geomorphology in South-western Ontario, Canada: An example of tectonic predesign. Geomorphology 19. (1-2): 17-34. Available at https://doi.org/10.1016/S0169555X(96)00050-5

Gioia, D., Schiattarella, M. and Giano, S.I. 2018. Right-angle pattern of minor fluvial networks from the Ionian terraced belt, Southern Italy: Passive structural control or foreland bending? Geosciences 8. (9): 331. Available at https://doi.org/10.3390/ geosciences 8090331

Gyalog, L. and Síkhegyi, F. 2005. Geological map of Hungary (M-34-138, Miskolc) 1:100 000. Ed.: RóNAI, A. and Less, Gy., Budapest, Hungarian Institute of Geology and Geophysics.

Hevesi, A. 1978. A Bükk szerkezet- és felszínfejlődésének vázlata (Structural and landscape development of Bükk Mountains). Földrajzi Értesítő / Hungarian Geographical Bulletin 27. (2): 169-203.

Hevesi, A. 2002a. A Bükk hegység földrajzi helyzete, kialakulása, éghajlata (Geographical position, formation and climate of the Bükk Mountains). In A Bükki Nemzeti Park. Ed.: Baráz, Cs., Eger, Bükki Nemzeti Park Igazgatóság, 15-22.

Hevesi, A. 2002b. Fejlődéstörténet II. Felszínfejlődés (Surface evolution II. Surface development). In $A$ Bükki Nemzeti Park. Ed.: Baráz, Cs., Eger, Bükki Nemzeti Park Igazgatóság, 83-108.

Hevesi, A. 2003. A Kárpát-medence és a Kárpátok természetföldrajzi tájtagolása. Budapest (Taxonomy 
of natural landscapes in the Carpathian Basin and Carpathiens). Földrajzi Értesító / Hungarian Geographical Bulletin 52. (3-4): 253-267.

Hevesi, A. and Záhorszki, A. 2000. A MiskolcTapolcai Kőmázsák és környékük 1:10 000 felszínalaktani térképezésének eddigi eredményei (The results of the 1:10,000 geomorphological mapping of the Miskolc-Tapolca Kömázsák and their surroundings). Karsztfejlődés 5. 41-45.

Jordán, Gy. and Csillag, G. 2003. GIS framework for morphotectonic analysis - a case study. In Proceedings of Fourth European Congress on Regional Geoscientific Cartography and Information Systems, Vol. 2. Bologna, Servizio Geologico, 516-519.

Leech, D.P., Treloar, P.J., Lucas, N.S. and GrocotT, J. 2003. Landsat TM analysis of fracture patterns: a case study from the coastal cordillera of northern Chile. International Journal of Remote Sensing 24. (19): 3709-3726. Available at https://doi. org/10.1080/0143116031000102520

Less, Gy., Kovács, S., Pelikán, P., Pentelényi, L. and SÁsDi, L. 2005. Geology of the Bükk Mountains. Explanatory book to the geological map of the Bükk Mountains (1:50,000). Budapest, Hungarian Institute of Geology and Geophysics.

Lukács, R., Harangi, Sz., Guillong, M., Bachmann, O., Fodor, L., Buret, Y., Dunkl, I., Sliwinski, J., von Quadt, A., Peytcheva, I. and Zimmerer, M. 2018. Early to Mid-Miocene syn-extensional massive silicic volcanism in the Pannonian Basin (East Central Europe): Eruption chronology, correlation potential and geodynamic implications. EarthScience Reviews 179. 1-19.

Lundmark, M.A., Augland, L.E. and Jørgensen, S.V. 2020. Digital fieldwork with Fieldmove - how do digital tools influence geoscience students' learning experience in the field? Journal of Geography in Higher Education 44. (3): 427-440. Available at https://doi.org/10.1080/03098265.2020.1712685

Márton, E. and Fodor, L. 1995. Combination of paleo-magnetic and stress data - a case study from North Hungary. Tectonophysics 242. (1-2): 99-114. Available at https://doi.org/10.1016/00401951(94)00153-Z

Martz, L. and Garbrecht, J. 1992. Numerical definition of drainage networks and subcatchment areas from digital elevation models. Computers and Geosciences 18. 747-761. Available at https://doi. org/10.1016/0098-3004(92)90007-E

Néмeth, N. 2005. A Délkeleti-Bükk keleti részének szerkezetföldtani viszonyai (Structural geological conditions of the eastern part of South-Eastern Bükk). PhD Thesis. Miskolc, University of Miskolc.

Pecsmány, P. 2017. A Bükkalja medencéinek kimutatása digitális felszínmodellen végzett statisztikai vizsgálatokkal (DEM based morphometrical studies for the Bükkalja basins detection). Miskolc, PhD Forum, $57-67$.
Pecsmány, P. 2021. A Bükkalja völgyhálózatának rendűség szerinti iránystatisztikai vizsgálata (Quantitative analysis of drainage network direction in the Bükkalja). Multidisciplinary Sciences 11. (2): 9-16. Available at https://doi.org/10.35925/j. multi.2021.2.2

Pecsmány, P., Hegedús, A. and Vágó, J. 2020. Remnant surfaces in the Tárkány Basin. Landscape and Environment (Acta Geographica Debrecina) 14. (2): 20-30. Available at https://doi. org $/ 10.21120 \% 2 F L E \% 2 F 14 \% 2 F 2 \% 2 F 2$

Pecsmány, P. and Vágó, J. 2020. A mélyszerkezet és a domborzat közötti kapcsolat a Bükkalja területén (Relationship between geological structure elements and surface in the Bükkalja). Müszaki Földtudományi Közlemények 89. (1): 29-34.

PentelénYI, L. 2002. A Bükkalja I. Földtani vázlat (Bükkalja I. Geological sketch). In A Bükki Nemzeti Park. Ed.: Baráz, Cs., Eger, Bükki Nemzeti Park Igazgatóság, 205-216.

PentelénYI, L. 2005. A bükkaljai miocén piroklasztikum összlet (The Miocene pyroclastic assemblage of Bükkalja). In A Bükk hegység földtana. Magyarázó a Bükk-hegység földtani térképéhez (1:50 000). Ed.: Pelikán, P., Budapest, MÁFI, 110-125.

Petrik, A. 2016. A Bükk déli előterének kainozóos szerkezetalakulása (Cenozoic structural evolution of the Southern Bükk foreland). PhD Thesis. Budapest, ELTE-TTK.

Petrik, A., Beke, B. and Fodor, L. 2014. Combined analysis of faults and deformation bands reveals the Cenozoic structural evolution of the southern Bükk foreland (Hungary). Tectonophysics 633. 3-62. Available at https://doi.org/10.1016/j. tecto.2014.06.029

Petrik, A., Beke, B., Fodor, L. and Lukács, R. 2016. Cenozoic structural evolution of the southwestern Bükk Mts. and southern part of the Darnó Deformation Belt (NE Hungary). Geologica Carpathica 67. (1): 83-104. Available at https://doi. org/10.1515/geoca-2016-0005

Petrik, A. and Jordán, Gy. 2017. Systematic digital terrain model construction and model verification with multi-source field data. Morphotectonic analysis in the Villány Hills and its surroundings, SW Hungary. Carpathian Journal of Earth and Environmental Sciences 12. (1): 207-224.

Pinczés, Z., Martonné Erdős, K. and Dobos, A. 1993. Eltérések és hasonlóságok a hegylábfelszínek pleisztocén felszínfejlődésében (Differences and similarities in the Pleistocene surface evolution of foothill areas). Földrajzi Közlemények 117. (3): 149-162.

Radaideh, O.M.A., Grasemann, B., Melichar, R. and Mosar, J. 2016. Detection and analysis of morphotectonic features utilizing satellite remote sensing and GIS: An example in SW Jordan. Geomorphology 275. 58-79. Available at https://doi.org/10.1016/j. geomorph.2016.09.033 
Ramsay, J.G. and Huber, M.I. 1985. The Techniques of Modern Structural Geology. Vol. 2. Folds and Fractures. London, Academic Press.

Ricchetti, E. and Palombella, M. 2007. Production of geological lineament map of southern Italy using landsat 7 ETM + imagery. Italian Journal of Geosciences 126. (3): 567-572. Available at http:// dx.doi.org/10.13140/RG.2.1.4268.4328

Ruszkiczay-Rüdiger, Zs., Fodor, L., Horváth, E. and Telbisz, T. 2007. Folyóvízi, eolikus és neotektonikai hatások szerepe a Gödöllői-dombság felszínfejlődésében - DEM-alapú morfometriai vizsgálat (Role of fluvial, eolian and neotectonical process in Gödöllő Hills landscape evolution - DEM based morphometrical studies). Földrajzi Közlemények 131. (4): 319-342.

Ruszkiczay-Rüdiger, Zs., Fodor, L., Horváth, E. and Telbisz, T. 2009. Discrimination of fluvial, eolian and neotectonic features in a low hilly landscape: A DEM-based morphotectonic analysis in the Central Pannonian Basin, Hungary. Geomorphology 104. (3-4): 203-217. Available at https://doi.org/10.1016/j. geomorph.2008.08.014

SCHRÉTER, Z. 1912. Eger környékének földtani viszonyai (Geological settings of the Eger Region). MÁFI Report. Budapest, MÁFI, 130-146.

SChréter, Z. 1926. Az 1925 január 31-i egri földrengés (The earthquake of Eger on January 31, 1925). Bulletin of the Hungarian Geological Society 55. 26-49.

Schréter, Z. 1933. A Bükk-hegység délkeleti oldalának földtani viszonyai (Geological conditions on the south-eastern side of the Bükk Mountains). Report on the 1932-34 geological survey. Budapest, MÁFI, 511-526.
Smith, S., Rouke, P.J., Ellis, J.F., Dunlor, C., Muir, R.J., Vaughan, A.P.M. and Anderson, H. 2014. Guiding field mapping with integrated digital mapping and model building. Australian Earth Sciences Convention, AESC. Newcastle (Poster).

Strahler, A.M. 1957. Quantitative analysis of watershed geomorphology. Transaction of the American Geophysical Union 38. 913-920. Available at https:// doi.org/10.1029/TR038i006p00913

Szalai, K. 2004. Geomorfológiai vizsgálatok az Upponyiszigethegységben és elöterein, különös tekintettel a földtani adottságokra (Geomorphological research in the Uppony Hills and its foregrounds, with special respect to the role of geological characteristics). PhD Thesis. Debrecen, University of Debrecen.

Twiss, R.J. and Moores, E.M. 1992. Structural Geology. New York, Freeman \& Co.

Unger, Z. and Timár, G. 2005. Székelyföld lineaens térképe Landsat TM ürfelvételek alapján (Lineament map of Szeklersland based on a Landsat-TM satellite image). Bulletin of the Hungarian Geological Society 135. (2): 293-304.

VÁGó, J and Hegedús, A. 2010. DEM-based examination of pediment levels: a case study in Bükkalja, Hungary. Hungarian Geographical Bulletin 60. (1): 25-44.

VÁGó, J. 2012. A kőzetminőség szerepe a Bükkalja völgyés vízhálózatának kialakulásában (The effects of rock quality on the drainage network of Bükkalja). PhD Thesis. Miskolc, University of Miskolc. 
